\title{
Tyrosine Hydroxylase in Human Adrenal and Pheochromocytoma: Localization, Kinetics, and Catecholamine Inhibition
}

\author{
J. C. Waymire, N. Weiner, F. H. Schneider, M. Goldstein, and \\ L. S. FrEedMaN \\ From the Department of Pharmacology, University of Colorado School of \\ Medicine, Denver, Colorado 80220 and the Department of Psychiatry, \\ New York University Medical Center, New York 10016
}

\begin{abstract}
A B S T R A C T The properties of partially purified tyrosine hydroxylase from six pheochromocytomas were compared with partially purified normal human and bovine adrenal medulla enzyme. Substrate and inhibition kinetics, cofactor requirements, and intracellular localization of the enzyme from normal and tumor chromaffin tissue of humans were similar, as was the amount of enzyme activity per gram of tissue. Contrary to previous reports, the sensitivity to catecholamine inhibition of the pheochromocytoma enzyme from the six tumors studied was similar to that of both human and bovine adrenal medulla tyrosine hydroxylase. These results suggest that the excessive synthesis and secretion of catecholamines in some pheochromocytomas is not the result of a reduced sensitivity of tyrosine hydroxylase to catecholamine inhibition.
\end{abstract}

\section{INTRODUCTION}

The formation of dihydroxyphenylalanine (dopa) ${ }^{1}$ from tyrosine, catalyzed by tyrosine hydroxylase (TH), is considered to be the rate-limiting step in the biosynthesis of catecholamines $(1,2)$. In normal sympathetically innervated neural tissues, the biosynthesis is presumably regulated by feedback inhibition of $\mathrm{TH}$ by catecholamines in competition with the pteridine cofactor of the enzymic reaction (3).

Most human pheochromocytomas are known to secrete large quantities of catecholamines, as manifested by increased plasma catecholamine levels and urinary excretion of these compounds. It has been suggested that the elevated production of catechols in the pheochromocytoma

Received for publication 17 November 1971 and in revised form 25 February 1972.

1 Abbreviations used in this paper: $\mathrm{DBH}$, dopamine- $\beta$-hydroxylase; $\mathrm{DMPH}_{4}$, 6,7-dimethyltetrahydropterin; dopa, dihydroxyphenylalanine; $\mathrm{TH}$, tyrosine hydroxylase. may be the consequence of less effective catecholamine feedback regulation of synthesis in the tumor. Roth, Stjärne, Levine, and Giarman (4) observed that aluminatreated low speed supernates prepared from human pheochromocytoma synthesized more catecholamines than did similar preparations from human adrenal medullae of the same patients. The authors reported that catecholamine synthesis in nonfortified homogenates of pheochromocytoma was far less sensitive to inhibition by catechol compounds than similar preparations from normal chromaffin tissue. Nagatsu, Yamamoto, and Nagatsu (5) investigated the properties of $\mathrm{TH}$ from human pheochromocytoma, comparing them with similar preparations from bovine adrenal medulla. They observed that the tumor enzyme was stimulated by ferrous ion and 6,7-dimethyltetrahydropterin $\left(\mathrm{DMPH}_{4}\right)$, but found that the enzyme was less sensitive to inhibition by norepinephrine and epinephrine. In the presence of low concentrations of catecholamines and high concentrations of $\mathrm{DMPH}_{4}$, they observed stimulation of enzyme activity. Tyrosine hydroxylase from normal human adrenal medulla was not studied. Both groups concluded that abnormally high synthesis of catechols in pheochromocytoma may be due, in part, to insensitivity of tyrosine hydroxylase to end product feedback inhibition.

When human pheochromocytomas became available in our laboratories, we compared the partially purified $\mathrm{TH}$ from the tumor with that of a similarly purified enzyme from normal human adrenal. In preliminary experiments, catechol inhibition of $\mathrm{TH}$ was found to be simflar in all studies (6). A more thorough investigation of the enzyme was therefore undertaken. The present report describes the results of a study of six pheochromocytomas in our two laboratories. Substrate and inhibition kinetics as well as cofactor requirements are compared in partially purified $\mathrm{TH}$ from the tumors as well as from 
TABLE I

Subcellular Localization of Tyrosine Hydroxylase, Dopamine- $\beta-H y d r o x y l a s e$, and Catecholamines in Human Pheochromocytoma

\begin{tabular}{|c|c|c|c|c|c|c|}
\hline & \multicolumn{2}{|c|}{ Tyrosine hydroxylase activity } & \multicolumn{2}{|c|}{ Dopamine- $\beta$-hydroxylase activity } & \multicolumn{2}{|c|}{ Catecholamine level* } \\
\hline & per $\mathbf{g}$ tissuef & per mg protein $t$ & per $\mathbf{g}$ tissue $\delta$ & per mg protein $\|$ & per $\mathbf{g}$ tissue & per mg protein \\
\hline & \multicolumn{2}{|c|}{ Hmoles } & \multicolumn{2}{|c|}{ 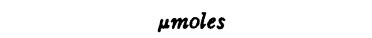 } & \multicolumn{2}{|c|}{$m g$} \\
\hline Whole homogenate & 3.4 & 0.043 & 0.047 & 0.59 & 2.86 & 3.5 \\
\hline $7,000 \mathrm{~g} \cdot \mathrm{min}$ supernate & 3.4 & 0.055 & 0.064 & 1.35 & 2.58 & 4.1 \\
\hline $235,000 \mathrm{~g} \cdot \mathrm{min}$ supernate & 4.7 & 0.199 & 0.028 & 1.18 & 0.62 & 2.5 \\
\hline $235,000 \mathrm{~g} \cdot \mathrm{min}$ pellet & 0.2 & 0.012 & 0.083 & 4.77 & 1.37 & 8.0 \\
\hline Chromaffin granule & 0.1 & 0.044 & 0.214 & 118.67 & 0.71 & 39.2 \\
\hline \multicolumn{7}{|l|}{ Chromaffin granule } \\
\hline membrane & 0.1 & $-\boldsymbol{T}$ & 2.665 & $-\Phi$ & none & - \\
\hline
\end{tabular}

* Milligrams catecholamine, $95 \%$ norepinephrine.

$\ddagger$ Activity expressed as micromoles product formed per hour using tyrosine hydroxylase assay 2 . Incubations included $100 \mu \mathrm{M}$

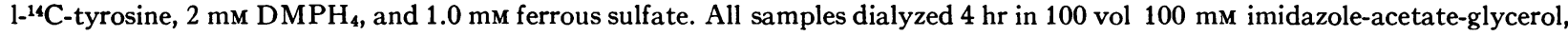
$\mathrm{pH}$ 7.0.

\$ Activity expressed as micromoles product formed per hour.

|| Activity expressed as nanomoles product formed per hour.

II Protein determination not performed.

Values represent average of duplicate assays done on each fraction from pheochromocytoma No. 1.

normal human and bovine adrenal medullae. The subcellular distribution of the enzyme in the three tissues is also reported since the localization of $\mathrm{TH}$ relative to the storage site of catecholamines (chromaffin granule) may be an important factor in feedback regulation of synthesis.

\section{METHODS}

\section{Chemicals}

The artificial cofactor for the assay of tyrosine hydroxylase, 6,7-dimethyl-5,6,7,8-tetrahydropterin $\left(\mathrm{DMPH}_{4}\right)$ was pur chased from Aldrich Chemical Co., Inc., Milwaukee, Wis. $\left[3,5-{ }^{3} \mathrm{H}\right]-\mathrm{L}-\mathrm{T}$ yrosine $(1,000 \mathrm{mCi} / \mathrm{mmole})$ and $\left[1-{ }^{14} \mathrm{C}\right]-\mathrm{L}$-tyrosine $(52 \mathrm{mCi} / \mathrm{mmole})$ were purchased from New England Nuclear Corp., Boston, Mass. $\left[1-{ }^{14} \mathrm{C}\right]-\mathrm{L}-\mathrm{T}$ yrosine required no purification; $\left[3,5-{ }^{3} \mathrm{H}\right]-\mathrm{L}$-tyrosine was purified as described by Ikeda, Fahien, and Udenfriend (7). All other chemicals were obtained from standard commercial sources.

\section{Radiochemical assay of tyrosine hydroxylase}

Assay 1, isolation and assay of ${ }^{3} \mathrm{H}_{2} \mathrm{O}$. Tyrosine hydroxylase activity was determined by a modification of the method of Nagatsu, Levitt, and Udenfriend (8). The assay contained $100 \mathrm{~mm}$ Tris-maleate, $\mathrm{pH} 5.9,0.5-2.0 \mathrm{~mm} \mathrm{DMPH}_{4}$ 0.5-1.0 mM ferrous sulfate, $50 \mathrm{~mm}$ mercaptoethanol, and $200 \mu \mathrm{M}\left(3,5-^{3} \mathrm{H}\right)$ - $\mathrm{L}$-tyrosine $(5.0 \mu \mathrm{Ci} / \mu$ mole $)$. Incubations were stopped by the addition of glacial acetic acid. The tubes were centrifuged, and a portion of the supernate transferred to a column $(0.5 \times 3.0 \mathrm{~cm})$ of Dowex $50-\mathrm{H}^{+}$ (Dow Chemical Co., Midland, Mich.). The tritiated water in the effluent and wash was counted by liquid scintillation spectrometry using $15 \mathrm{ml}$ of Bray's solution (9). The radioactivity was determined in a Packard Tri-Carb liquid scintillation spectrophotometer (Packard Instrument Co.,
Inc., Downers Grove, Ill.). Activity, corrected for quenching, is expressed as micromoles ${ }^{8} \mathrm{H}_{2} \mathrm{O}$ released per unit time. Assay 2, formation and assay of ${ }^{14} \mathrm{CO}_{2}$. This recently developed procedure (10) incorporates the recovery and assay of ${ }^{14} \mathrm{CO}_{2}$ after quantitative decarboxylation with partially purified hog kidney aromatic L-amino acid decarboxylase of carboxyl-labeled dopa formed from carboxyl-labeled tyrosine. The assay contained $100 \mathrm{~mm}$ sodium acetate, $\mathrm{pH}$ $6.1,0.5-2.0 \mathrm{~mm} \mathrm{DMPH}_{4} \quad 0.5-1.0 \mathrm{~mm}$ ferrous sulfate, 50 $\mathrm{mm}$ 2-mercaptoethanol, and $100 \mu \mathrm{M}\left[1-{ }^{14} \mathrm{C}\right]$-L-tyrosine (10 $\mu \mathrm{Ci} / \mu$ mole $).{ }^{14} \mathrm{CO}_{2}$ was collected in $0.2 \mathrm{ml} \mathrm{NCS}$ solubilizer (Nuclear-Chicago Corporation, Des Plaines, Ill.) and was counted by liquid scintillation spectrometry using $15 \mathrm{ml}$ toluene containing $0.5 \mathrm{~g}$ 1,4-bis (2[4-methyl-5-phenyloxazolyl]) benzene and $4.0 \mathrm{~g}$ 2,5-diphenyloxazole per liter. Activity is expressed as micromoles ${ }^{14} \mathrm{CO}_{2}$ collected per unit time.

\section{Assay of dopamine- $\beta$-hydroxylase}

Dopamine- $\beta$-hydroxylase (DBH) activity was assayed in the presence of $10^{-5} \mathrm{M}$ para-chloromercuribenzoate by the procedure of Viveros, Arqueros, Connett, and Kirshner (11). Activity is expressed as micromoles of octopamine formed per unit time.

\section{Assay of catecholamines}

Catecholamines were measured by the colorimetric method of von Euler and Hamberg (12) using citrate-phosphate buffer at $\mathrm{pH} 6.0$.

\section{Subcellular tissue fractionation}

Human adrenal glands were obtained either postmortem from the pathologist in cases where no adrenal pathology was present or from accident victims who were being maintained as organ donors by the Colorado General Hospital transplantation team. Human pheochromocytomas were ob- 
TABLE II

Subcellular Localization of Tyrosine Hydroxylase in Three Chromaffin Tissues

\begin{tabular}{|c|c|c|c|}
\hline \multirow[b]{2}{*}{ Fraction } & \multicolumn{3}{|c|}{ Tyrosine hydroxylase activity* $¥$} \\
\hline & $\begin{array}{l}\text { Human adrenal } \\
\text { medulla }\end{array}$ & $\begin{array}{l}\text { Bovine adrenal } \\
\text { medulla§ }\end{array}$ & $\begin{array}{c}\text { Human } \\
\text { pheochro- } \\
\text { mocytoma } 2\end{array}$ \\
\hline & \multicolumn{3}{|c|}{ $\mu$ moles } \\
\hline $\begin{array}{l}\text { Whole homogenate } \\
7,000 \mathrm{~g} \cdot \mathrm{min}\end{array}$ & 3.57 & 3.49 & 2.08 \\
\hline $\begin{array}{l}\text { supernate } \\
235,000 \mathrm{~g} \cdot \mathrm{min}\end{array}$ & 3.57 & 4.43 & 1.91 \\
\hline $\begin{array}{l}\text { pellet } \\
235,000 \mathrm{~g} \cdot \mathrm{min}\end{array}$ & 0.24 & 2.96 & 0.80 \\
\hline supernate & 2.38 & 3.00 & 4.32 \\
\hline
\end{tabular}

* Micromoles product formed/gram tissue per hour using tyrosine hydroxylase assay 2 . Incubations included $100 \mu \mathrm{M} \mathrm{1-14}$-tyrosine, $2 \mathrm{~mm}$ $\mathrm{DMPH}_{4}$, and $1.0 \mathrm{~mm}$ ferrous sulfate.

$\ddagger$ All samples dialyzed $4 \mathrm{hr}$ in 100 vol $100 \mathrm{~mm}$ imidazole-acetate-glycerol pH 7.0.

Representative of typical distribution pattern for tissue.

Values represent average of duplicate assays done on each fraction.

tained immediately after surgical removal and placed in icecold $0.3 \mathrm{M}$ sucrose. Bovine adrenal glands were obtained from the animal at time of slaughter. All tissues were minced and homogenized in $3 \mathrm{vol}$ of $0.3 \mathrm{M}$ sucrose using five strokes with a loose fitting Teflon pestle $(0.8 \mathrm{~mm}$ clearance). All fractionation procedures were carried out at $0^{\circ} \mathrm{C}$.

Homogenates were centrifuged at low speed $(7,000 \mathrm{~g}$. min). The sediment contained cell nuclei, unbroken cells, and debris. The cytoplasmic extract was further centrifuged at $235,000 \mathrm{~g} \cdot \mathrm{min}$ and at $6 \times 10^{\circ} \mathrm{g} \cdot \mathrm{min}$ to yield the large granule fraction and microsomal pellet, respectively. Chromaffin granules were isolated by passing $1 \mathrm{ml}$ of the resuspended large granule fraction through $9.0 \mathrm{ml} 1.8 \mathrm{M}$ sucrose at $12 \times 10^{\circ} \mathrm{g} \cdot \mathrm{min}$. All samples were assayed after

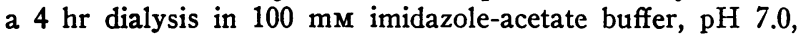
containing $10 \%$ glycerol. This procedure has been found to remove catecholamines while preserving tyrosine hydroxylase activity.

\section{Partial purification of tyrosine hydroxylase}

Soluble tyrosine hydroxylase was used as a starting material for all purifications. The enzyme was either fractionated

TABLE III

Tyrosine Hydroxylase Activities in Pheochromocytoma and Normal Tissues

\begin{tabular}{lc}
\hline \multicolumn{1}{c}{ Tissues } & Tyrosine hydroxylase* activity \\
\hline & $\mu$ moles $/ \mathrm{g}$ tissue per $\mathrm{hr}$ \\
Pheochromocytoma (malignant) & 3.44 \\
Pheochromocytoma (benign) 2 & 2.08 \\
Human adrenal medulla & 3.57 \\
Rat adrenal medulla & 1.57 \\
Bovine adrenal medulla & 3.49
\end{tabular}

* Determined on whole homogenates dialyzed against 100 vol $100 \mathrm{~mm}$ imidazole-acetate, $\mathrm{pH} \quad 7.0-10 \%$ glycerol to remove catecholamines using assay 2. Incubation included $100 \mu \mathrm{M} 1-14 \mathrm{C}$-tyrosine, $2 \mathrm{mM} \mathrm{DMPH}_{4}$, and $1 \mathrm{~mm}$ ferrous sulfate. with ammonium sulfate (25-37\% saturation) and dialyzed 4 $\mathrm{hr}$ in $100 \mathrm{~mm}$ imidazole-acetate buffer, $\mathrm{pH} \mathrm{7.0,} \mathrm{containing}$ $10 \%$ glycerol, or purified according to Nagatsu et al. (5), (two ammonium sulfate fractionations, $0-40 \%$ saturation and then $25-35 \%$ saturation, charcoal treatment, and chromatography on a hydroxyapatite column).

\section{RESULTS}

Subcellular fractionation of two human pheochromocytomas gave similar results. In the fractionation study shown in Table $I$, dopamine- $\beta$-hydroxylase (DBH) and catecholamines were used as markers for the localization of the chromaffin granules. Tyrosine hydroxylase appeared almost entirely in the soluble fraction while DBH was associated with the chromaffin granules. Table II gives the results of a comparison of $\mathrm{TH}$ localization in three tissues: human pheochromocytoma, human adrenal, and bovine adrenal. Both the human
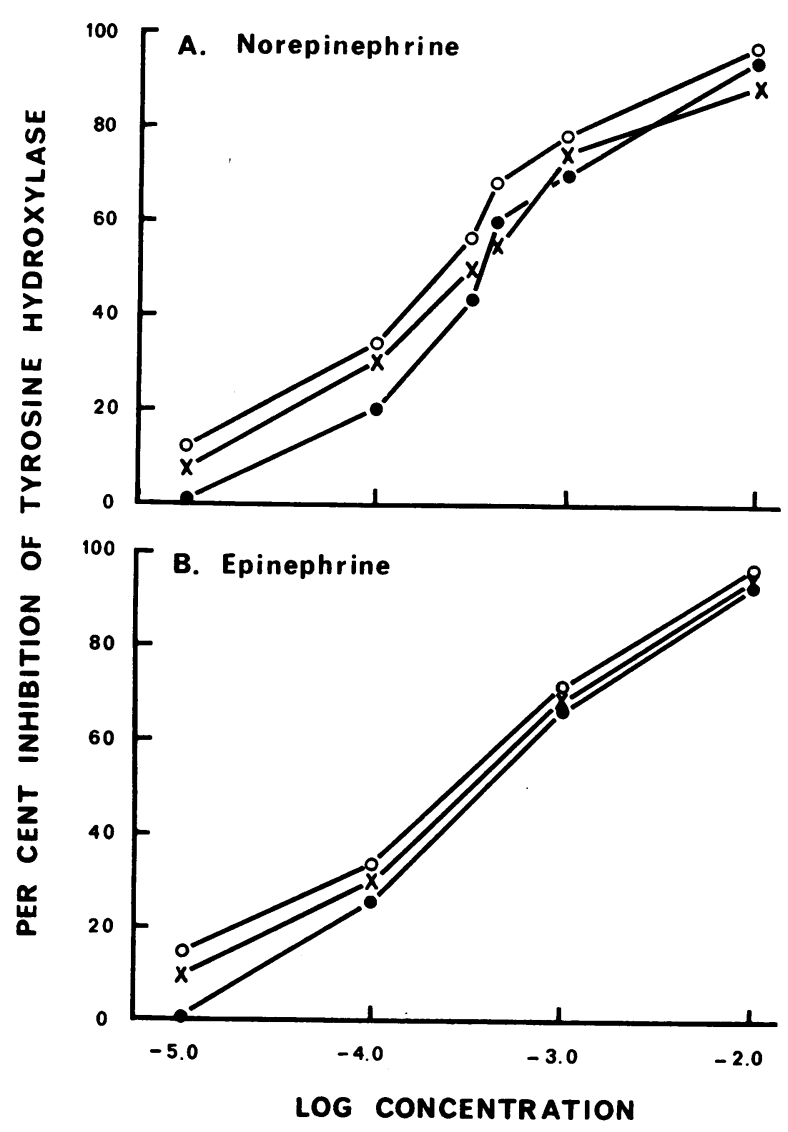

FIgURE 1 Per cent inhibition of normal human adrenal and human pheochromocytoma tyrosine hydroxylase over a wide range of inhibitor concentrations of: (a) norepinephrine and $(b)$ epinephrine. Activity measured using assay 2. Incubation included $100 \mu \mathrm{M}{ }^{1-1} \mathrm{C}$-tyrosine, $2 \mathrm{mM}$ $\mathrm{DMPH}_{4}, 1.0 \mathrm{~mm}$ ferrous sulfate, and catecholamine as indicated. $-\bullet$, tumor $2 ; 0-0$, tumor $1 ; \times-\times$, normal human adrenal. 
TABLE IV

Comparison of Cofactor Requirements for Tyrosine Hydroxylase from Three Chromaffin Tissues

\begin{tabular}{|c|c|c|c|}
\hline \multirow[b]{2}{*}{ Condition } & \multicolumn{3}{|c|}{ Amount of tyrosine hydroxylase in complete system } \\
\hline & $\begin{array}{l}\text { Bovine adrenal } \\
\text { medulla }\end{array}$ & $\begin{array}{l}\text { Human adrenal } \\
\text { medulla }\end{array}$ & $\begin{array}{c}\text { Human } \\
\text { pheochromocytoma }\end{array}$ \\
\hline & $\%$ & $\%$ & $\%$ \\
\hline Complete system* & 100.00 & 100.00 & 100.00 \\
\hline$-\mathrm{DMPH}_{4}$ & 0.00 & 0.00 & 0.00 \\
\hline$-\mathrm{Fe}^{++}$ & 0.90 & 6.40 & 10.00 \\
\hline $1.0 \mathrm{~mm} \alpha, \alpha^{\prime}$-dipyridyl & 0.03 & 0.04 & 0.04 \\
\hline $1.0 \mathrm{~mm} \alpha, \alpha^{\prime}$-dipyridyl with $2.0 \mathrm{~mm} \mathrm{Fe} \mathrm{F}^{++}$ & 96.20 & 96.50 & 96.00 \\
\hline +Catalase $(2500 \mathrm{U}) \ddagger$ & 100.00 & 100.00 & 100.00 \\
\hline$-\mathrm{Fe}^{++},+$catalase $(2500 \mathrm{U})$ & 37.50 & 30.20 & 24.50 \\
\hline$+1.0 \mathrm{mM} \alpha, \alpha^{\prime}$-dipyridyl and catalase (5000 U) & 0.05 & 0.02 & 0.06 \\
\hline$+2.0 \mathrm{~mm} 3$-iodotyrosine & 0.00 & 0.00 & 0.00 \\
\hline
\end{tabular}

adrenal and pheochromocytoma $\mathrm{TH}$ are soluble. Bovine adrenal $\mathrm{TH}$ is distributed in all subcellular fractions. This is explicable on the basis of its adsorption to membrane fragments as has been previously reported (13).

Table III shows tyrosine hydroxylase activity in two pheochromocytoma tumors as well as in normal adrenals of human, rat, and cow. The enzyme activities in the tumor tissues are of the same order of magnitude and do not differ significantly from the activities found in normal adrenal medullae of these species.

The properties of $\mathrm{TH}$ separated from pheochromocytoma and human adrenal gland were similar to those of the enzyme from bovine adrenal medulla (Table IV). All three enzymes required a pteridine cofactor (DM$\mathrm{PH}_{4}$ ). Maximal activity was not possible without 1.0 mM ferrous sulfate; smaller concentrations of iron in the incubation gave proportionately less $\mathrm{TH}$ activity. The addition of the iron complexing agent, $\alpha, \alpha$-dipyridyl, resulted in the complete loss of activity. Addition of excess iron restored the activity to control levels. Shiman, Akino, and Kaufman (14) have recently suggested that catalase is effective in replacing ferrous iron in tyrosine hydroxylase incubations. In our studies $\mathrm{TH}$ activity is between 24.5 and $37.5 \%$ of control activity when catalase replaces iron. Excess iron is effective in reversing $\alpha, \alpha^{\prime}$-dipyridyl inhibition of the enzyme while catalase is not. 3-Iodotyrosine completely inhibits all three enzyme preparations.

Inhibition of $\mathrm{TH}$ from two pheochromocytomas by a wide range of concentrations of catecholamines is shown in Fig. 1. The results of a more thorough study of the inhibition of $\mathrm{TH}$ by catecholamines is shown in Table
V. Concentrations of catecholamines identical to those used by Nagatsu et al. (5) were tested for inhibition of the $\mathrm{TH}$ from six tumors and normal human adrenal medulla. Contrary to previous reports $(4,5)$, the enzyme from all tumors exhibited sensitivity to feedback inhibition similar to that found for either human adrenal medulla or bovine adrenal medulla. Inhibition was similar with norepinephrine, epinephrine, or dopamine.

Fig. 2, $a$ and $b$, illustrates the competitive nature of the catechol inhibition with respect to the pteridine

\section{TABLE V}

Effect of Catecholamine on Tyrosine Hydroxylase of Human Adrenal and Chromafin Cell Tumors

\begin{tabular}{|c|c|c|c|c|c|c|}
\hline \multirow[b]{2}{*}{ Enzyme source } & \multicolumn{6}{|c|}{$\begin{array}{l}\text { Amount tyrosine hydroxylase activity at } \\
\text { catecholamine concentration }(m \mathrm{M}) \|\end{array}$} \\
\hline & 0.00 & 0.10 & 0.20 & $0.33^{\circ}$ & 0.40 & 0.50 \\
\hline & \multicolumn{6}{|c|}{$\%$} \\
\hline Human adrenal* & 100 & 75 & 60 & 48 & - & 36 \\
\hline Pheochromocytoma 1* & 100 & 71 & - & 50 & - & 42 \\
\hline Pheochromocytoma 2* & 100 & 80 & 69 & 49 & 45 & 43 \\
\hline Pheochromocytoma 3‡ & 100 & 71 & 72 & 54 & - & 53 \\
\hline Pheochromocytoma $4 \S$ & 100 & 57 & 33 & 35 & - & 25 \\
\hline Pheochromocytoma $5 \S$ & 100 & - & 66 & 43 & - & 38 \\
\hline Pheochromocytoma $6 \delta$ & 100 & 68 & 47 & 36 & 一 & 29 \\
\hline
\end{tabular}

* Assay 2 carried out with $1.0 \mathrm{~mm}$ ferrous sulfate, $2.0 \mathrm{~mm} \mathrm{DMPH4}$, and $28-37 \%\left(\mathrm{NH}_{4}\right)_{2} \mathrm{SO}_{4}$ fraction of $100,000 \mathrm{~g}$ supernate as enzyme and epinephrine as inhibitor.

‡ Assay 1 carried out with $0.5 \mathrm{~mm}$ ferrous sulfate, $0.5 \mathrm{mM} \mathrm{DMPH}_{4}$, and $80 \%$ ammonium sulfate fraction of $100,000 \mathrm{~g}$ supernate as enzyme and norepinephrine as inhibitor.

8 Assay 1 carried out with $1.0 \mathrm{~mm}$ ferrous sulfate, $2.0 \mathrm{~mm} \mathrm{DMPH}$, and enzyme purified according to Nagatsu et al. (10) using norepinephrine as inhibitor.

$\|$ As per cent activity in absence of catecholamine. 
cofactor $\left(\mathrm{DMPH}_{4}\right)$ for both human adrenal and human pheochromocytoma TH. Table VI summarizes the calculated kinetic constants for $\mathrm{TH}$ from three sources. The apparent $K_{m}$ 's for $\mathrm{DMPH}_{4}$ and tyrosine are similar for the three. The $K_{1}$ values using epinephrine as inhibitor are approximately the same for the pheochromo. cytoma and human adrenal medulla enzyme. Norepinephrine gives similar results.

A

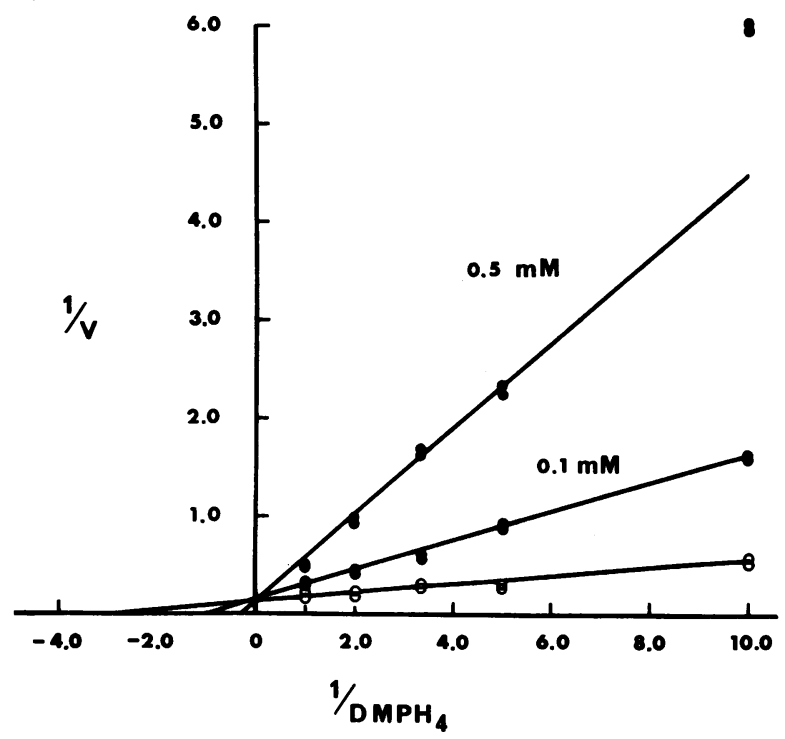

B

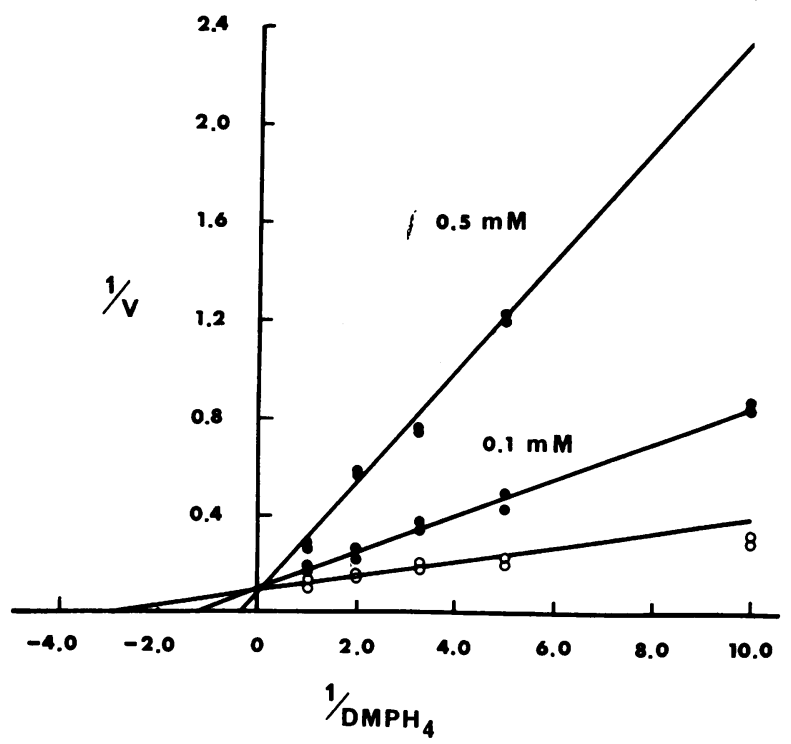

Figure 2 Lineweaver-Burk plot of tyrosine hydroxylase activity of (a) human adrenal medulla and $(b)$ human pheochromocytoma as a function of cofactor concentration (millimolar) (open circles). Analysis of inhibition by 0.1 and $0.5 \mathrm{~mm}$ epinephrine (closed circles). Activity measured using assay 2 .
TABLE VI

Kinetic Constants of Tyrosine Hydroxylase from Human Adrenal Medulla and Pheochromocytoma

\begin{tabular}{lccc}
\hline \multicolumn{1}{c}{ Constant } & $\begin{array}{c}\text { Normal human } \\
\text { adrenal medulla }\end{array}$ & $\begin{array}{c}\text { Pheochro- } \\
\text { mocytoma } \\
\text { No. 1 }\end{array}$ & $\begin{array}{c}\text { Pheochro- } \\
\text { mocytoma } \\
\text { No. 2 }\end{array}$ \\
\hline$K_{m}$ tyrosine, $m \mathrm{M}$ & $0.079(1)$ & $0.129(1)$ & $0.097(1)$ \\
$K_{m}$ DMPH4, $m \mathrm{M}$ & $0.240(2)$ & $0.356(1)$ & $0.371(2)$ \\
$K_{i}$ epinephrine, $m \mathrm{M}$ & $0.037(4)$ & $0.031(1)$ & $0.055(3)$
\end{tabular}

Number in parentheses indicates number of experiments.

Activity measured using assay 2. Incubations included $1.0 \mathrm{mM}$ ferrous sulfate.

\section{DISCUSSION}

The properties of $\mathrm{TH}$ from all three sources examined (bovine adrenal, human adrenal, and human pheochromocytoma) are quite similar. The requirement of DM$\mathrm{PH}_{4}$ as a cofactor and stimulation of $\mathrm{Fe}^{2+}$ have been reported previously for both the bovine enzyme $(7,15)$ and the pheochromocytoma enzyme (5). Similar dependencies were observed for the $\mathrm{TH}$ from the human adrenal (Table IV). All three enzymes were capable of partial activity if catalase replaced iron in the incubation. The fact that only excess iron reverses $\alpha, \alpha^{\prime}-$ dipyridyl inhibition of $\mathrm{TH}$ while catalase is without effect may indicate that a small amount of iron is necessary to activate the enzyme (such as $\mathrm{Cu}^{++}$activates dopamine- $\beta$-hydroxylase) (16). Additional amounts of iron may inhibit the formation of peroxides and catalase could substitute in this role.

The Michaelis constants for DMPH4 and tyrosine were also quite similar in the enzymes from the two human sources (pheochromocytoma and adrenal medulla). The values agree closely with those published for bovine adrenal $\mathrm{TH}(7,15)$.

The most interesting observation in our series of experiments, however, is that the similarity of properties of the enzyme from normal and tumor tissue extends to sensitivity to catecholamine inhibition of $\mathrm{TH}$. In the cases investigated in our laboratories, biochemical and clinical findings indicated that the tumors were synthesizing and secreting large amounts of catecholamines before surgery. In contrast to previous reports, however, the sensitivity of the enzyme isolated from these (six) tumors did not differ from normal human adrenal TH over a wide range of catechol concentrations (Fig. $1 a$ and $b$ ). No stimulation of TH by catecholamines was found (Table V).

The substrate and inhibition kinetics of tyrosine hydroxylase from pheochromocytoma also approximated those of the enzyme from normal human adrenal (Fig. $2 a$ and $b$ and Table VI). The reason for the discrepancies between our results and those of Nagatsu et al. (5) and Roth et al. (4) is not clear, but may 
reflect the existence of distinct types of tyrosine hydroxylases in different chromaffin cell tumors. Alternatively, it is possible that different conditions in the isolation and assay of the different enzymes could account for the results obtained, although, in our studies, several isolation and assay methods were analyzed, including the procedure used by Nagatsu et al. (5).

It thus appears that, in at least some pheochromocytomas (all six that we studied), the mechanism of elevated synthesis and secretion is not via a less sensitive end product feedback inhibition. Roth and coworkers (4) report that in unfortified low speed supernates the level of synthesis per gram of tissue is greater in the tumor than in adrenal preparations from the same patients. Since they did not fortify their system with pterin cofactor, explanations for this could be a higher concentration of enzyme or endogenous cofactor in the tumor tissue or less sensitivity of the tumor enzyme to feedback inhibition. A comparison of the levels of the enzyme in normal adrenal tissue and in two tumors (Table III) indicates that, at least in the tumors we examined, there was no elevation of enzyme levels. Tyrosine hydroxylase activity per gram of tissue is of the same order of magnitude in all the tissues studied. No estimates of pteridine levels have been reported in either normal human chromaffin tissue or pheochromocytoma.

A possible mechanism for the elevated synthesis could be an abnormal distribution of $\mathrm{TH}$ relative to the chromaffin granule. Our results (Table I) indicate, however, that $\mathrm{TH}$ is similarly located in both the tumor and normal human chromaffin tissue. The localization of the enzyme in the cytosol agrees with that reported for other chromaffin tissues (13).

The finding of catecholamine/ATP ratios in chromaffin granules isolated from tumors which are higher than those found in chromaffin granules from normal adrenal tissue $(17,18)$ indicates a mechanism of storage different from that characteristic of amines in normal chromaffin granules. The amines in the latter granules are believed to be bound in a stoichiometric relationship to adenine nucleotides. Catecholamines may be taken up more readily and/or bound more tightly by the granules of the tumor tissue. The suggestion that the synthesis rate may be related to an exaggerated uptake and storage mechanism in these granules should be reconsidered since smaller amounts of the amine would be left in the soluble portion of the cell where tyrosine hydroxylase is located and where increased synthesis would occur as a result of reduced levels of the end products capable of inhibiting TH $(19,20)$.

Lower inhibition by catecholamines of pheochromocytoma tyrosine hydroxylase may be the cause of elevated synthesis in some, but not all, pheochromo- cytomas. At present the mechanism of increased synthesis in the pheochromocytomas we have studied remains obscure. It is of course quite possible that the increased levels of circulating catecholamines in patients with pheochromocytomas could be due merely to the increased mass of chromaffin tissue present in these individuals.

\section{ACKNOWLEDGMENTS}

This work was supported by U. S. Public Health Service Research Grants NS 07642, NS 07927, MH 02717, and NSF GB 27603.

\section{REFERENCES}

1. Levitt, M., S. Spector, A. Sjoerdsma, and S. Udenfriend. 1965. Elucidation of the rate-limiting step in norepinephrine biosynthesis in the perfused guinea-pig heart. J. Pharmacol. Exp. Ther. 148: 1.

2. Nagatsu, T., M. Levitt, and S. Udenfriend. 1964. Tyrosine hydroxylase: the initial step in norepinephrine biosynthesis. J. Biol. Chem. 239: 2910.

3. Udenfriend, S., P. Saltzman-Nirenberg, and T. Nagatsu. 1965. Inhibitors of purified beef adrenal tyrosine hydroxylase. Biochem. Pharmacol. 14: 837.

4. Roth, R. H., L. Stjärne, R. J. Levine, and N. J. Giarman. 1968. Abnormal regulation of catecholamine synthesis in pheochromocytoma. J. Lab. Clin. Med. 72:397.

5. Nagatsu, T., T. Yamamoto, and I. Nagatsu. 1970. Partial separation and properties of tyrosine hydroxylase from human pheochromocytoma: effect of norepinephrine. Biochem. Biophys. Acta. 198: 210.

6. Goldstein, M., T. H. Joh, and H. Gang. 1970. Some aspects of the biosynthesis of catecholamines in adrenal glands and in pheochromocytoma and neuroblastoma tumors. Int. Cong. Clin. Chem. 7th. 3: 78.

7. Ikeda, M., L. A. Fahien, and S. Udenfriend. 1966. A kinetic study of bovine adrenal tyrosine hydroxylase. J. Biol. Chem. 241 : 4452.

8. Nagatsu, T., M. Levitt, and S. Udenfriend. 1964. A rapid and simple radioassay for tyrosine hydroxylase activity. Anal. Biochem. 9: 122.

9. Bray, G. A. 1960. A simple efficient liquid scintillator for counting aqueous solutions in a liquid scintillation counter. Anal. Biochem. 1: 279.

10. Waymire, J. C., R. Bjur, and N. Weiner. 1971. Assay of tyrosine hydroxylase by coupled decarboxylation of dopa formed from $1{ }^{14} \mathrm{C}$-tyrosine. Anal. Biochem. 43: 588.

11. Viveros, O. H., L. Arqueros, R. J. Connett, and N. Kirshner. 1969. Mechanisms of secretion from the adrenal medulla. III. Studies of dopamine- $\beta$-hydroxylase as a marker for catecholamine storage vesicle membranes in rabbit adrenal glands. Mol. Pharmacol. 5 : 60 .

12. von Euler, U. S., and U. Hamberg. 1949. Colorimetric determination of noradrenaline and adrenaline. Acta Physiol. Scand. 19: 74 . 
13. Musacchio, J. M. 1968. Subcellular distribution of adrenal tyrosine hydroxylase. Biochem. Pharmacol. 17: 1470.

14. Shiman, R., M. Akino, and S. Kaufman. 1971. Solubilization and partial purification of tyrosine hydroxylase from bovine adrenal medulla. J. Biol. Chem. 246: 1330.

15. Shiman, R., and S. Kaufman. 1970. Tyrosine hydroxylase (bovine adrenal glands). Methods Enzymol. 18:609.

16. Friedman, S., and S. Kaufman. 1965. 3,4-dihydroxyphenylethylamine- $\beta$-hydroxylase: a copper protein. $J$. Biol. Chem. 240: PC 552.
17. Gelinas, R., J. Pellerin, and A. D'Iorio. 1957. Biochemical observations of a chromaffin tumor. Rev. Can. Biol. $16: 445$.

18. Stjärne, L., U. S. von Euler, and F. Lishajko. 1964. Catecholamines and nucleotides in pheochromocytoma. Biochem. Pharmacol. 13: 809.

19. Weiner, N. 1970. Regulation of norepinephrine biosynthesis. Ann. Rev. Pharmacol. 10: 273.

20. Alousi, A., and N. Weiner. 1966. The regulation of norepinephrine synthesis in sympathetic nerves: effect of nerve stimulation, cocaine and catecholamine-releasing agents. Proc. Nat. Acad. Sci. U. S. A. 56: 1491. 